\title{
Genital morphology of the male South American fur seal (Arctocephalus australis) and biological implications ${ }^{1}$
}

\author{
Alex Sander D. Machado ${ }^{2 *}$, Alfredo Le Bas ${ }^{3}$, Maria Angélica Miglino², Rudolf Leiser ${ }^{4}$ \\ and Paula de Carvalho Papa ${ }^{2}$
}

\begin{abstract}
Machado A.S.D., Le Bas A., Miglino M.A., Leiser R. \& Papa P.C. 2012. Genital morphology of the male South American fur seal (Arctocephalus australis) and biological implications. Pesquisa Veterinária Brasileira 32(Supl.1):67-78. Setor de Anatomia do Departamento de Cirurgia, Faculdade de Medicina Veterinária e Zootecnia, Universidade de São Paulo, Av. Prof. Dr. Orlando Marques de Paiva 87, São Paulo, SP 05508-270, Brazil. E-mail: mamiferomarinho@gmail.com

Male capacity for spreading genes to a great number of descendents and to determine population dynamics depend directly on the genital organs. Morphological studies in pinnipeds are scarce and the functional meaning of some characteristics has never been discussed. We hypothesized that Arctocephalus australis (A. australis) shows morphophysiological adaptations in order to guarantee the perpetuation of the species in the unique annual mating season. Seven males, dead from natural causes, had their genital organs collected and fixed for morphological description. Some features differ from other described mammalian males and are closely related to the biology and reproductive cycle of this species, as the scrotal epidermis, absence of glandular portion in the ductus deferens and spermatogenic epithelium suggest a recrudescent testis period. The corona glandis exhibits a singular arrangement: its erectile border looks like a formation of petals and its association with the os penis gives a "lily-flower" form to this region. We propose the name margo petaliformis to this particular erectile border of the corona glandis because of its similarity to a flower corola. The male genital organs of $A$. australis show morphological features compatible with adaptation to environment requirements and reproductive efficiency.
\end{abstract}

INDEX TERMS: Male genital organs, South American fur seal, Arctocephalus australis, morphophysiology.

RESUMO.- [Morfologia dos órgãos genitais do macho do Lobo marinho (Arctocephalus australis) e implicações biológicas.]A capacidade do macho de espalhar seus genes a um grande número de descendentes e determinar a dinâmica populacional depende diretamente dos seus órgãos genitais. Estudos morfológicos em pinípedes são escassos e o significado funcional de algumas de suas características

\footnotetext{
${ }^{1}$ Received on September 10, 2012.

Accepted for publication on October 11, 2012.

${ }^{2}$ Setor de Anatomia do Departamento de Cirurgia, Faculdade de Medicina Veterinária e Zootecnia, Universidade de São Paulo (USP), Av. Prof. Orlando Marques de Paiva 87, São Paulo, SP 05508-270, Brazil. Address of the author: Rua Macau de Baixo 259, Diamantina, MG 39100-000, Brazil. *Corresponding author: mamiferomarinho@gmail.com

${ }^{3}$ Seccion de Fisiologia, Faculdad de Ciencias, Universidad de la Republica, Piso 10, Ala Sur, Igua 4225, Montevideo, 11400, Uruguay.

${ }^{4}$ Institut für Anatomie, Histologie und Embryology, Tiermedizinische Fakultät, Justus-Liebig-Universität Giessen, D-35392 Giessen, Germany. Address of the author: Av. Armando Marques de Paiva 87, São Paulo, SP 05508-270, Brazil.
}

ecológicas ainda foi pouco discutido. Nossa hipótese é que Arctocephalus australis (A. australis) apresenta adaptações morfofisiológicas em seus órgãos genitais capazes de interagir com o meio e garantir a perpetuação da espécie que apresenta apenas uma época de acasalamento que ocorre uma vez a cada ano. Sete $A$. australis machos, mortos recentes por causas naturais, tiveram seus órgãos genitais coletados e fixados para a descrição macro, micro e ultraestrutural. Algumas características diferem de outros machos já descritos e estão intimamente relacionados com a biologia e ciclo reprodutivo da espécie, dentre elas podemos citar a alta queratinização da epiderme escrotal que pode se relacionar com as rotineiras lesões por atrito desta região nas pedras; a ausência da porção glandular do ducto deferente aqui descrita pela primeira vez, o epitélio espermatogênico sugere um período de testículo recrudescente. A glande apresenta um arranjo singular: a coroa da glande apresenta porção lateral de tecido esponjoso que são bordas livres com capacidade de intumescencia. 0 osso peniano se en- 
contra no centro destas bordas e representa a extremidade mais distal do penis, levando consigo o óstio uretral externo. As bordas associadas ao osso peniano, dão uma forma de "Flor de lírio" a esta região. Utilizamos o nome margo petaliformis a margem erétil liliforme a particular morfologia da glande, pela sua semelhança a uma corola de flor. Os órgãos genitais masculinos de A. australis mostram características morfológicas compatíveis com uma adaptação aos requisitos ambientais e de eficiência reprodutiva.

TERMOS DE INDEXAÇÃO: Órgãos genitais masculinos, Lobo marinho sul Americano, Arctocephalus australis, morfologia, ecofisiologia.

\section{INTRODUCTION}

Anatomy and reproductive biology may be parameters which reflect the evolutionary status or ecologic adaptation of a species. Pinnipeds are generally polygamic and the occurrence of a unique annual mating season may explain the male's high reproductive efficiency. Most adult male Arctocephalus australis present the copulatory tactic of establishing a harem of up to seven females (Vaz-Ferreira 1976) annually in early summer (Atkinson 1997). However, low rates of paternity were described for territorial Antarctic fur seals (Arctocephalus gazella), which present the same reproductive tactic, demonstrating that others skills may be important for the reproductive success of male fur seals (Gemmell et al. 2001).

The South American Fur Seal, Arctocephalus australis (A. australis, Carnivora, Caniformia, member of the superfamily Phocoidea, family Otariidea, subfamily Arctocephalinae) (McKenna \& Bell 1998), is classified under 'lower risk and least concern' in threat status by the International Union for the Conservation of Nature and Natural Resources (IUCN 2010). Reproductive colonies are found along the east and west South American coast and islands, from

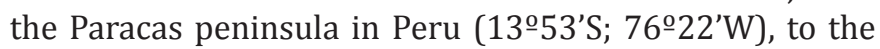
Beagle canal at the southern tip of the continent, and to the north coast of the eastern part of Uruguay (Vaz-Ferreira 1976, Ridgway \& Harrison 1993).

In the beginning of summer (October), A. australis males fight each other to delimit their territories on reproductive islands. The population density in a colony varies from 0.5 to 1.5 animals per square meter. The average size of each harem is 50 square meters (Trillmich \& Majluf 1981). The distance between the territories of each male varies with the topography and location of the land (Vaz-Ferreira \& Ponce de Leon 1984). After the establishment of the harem's territory, peri-parturient females arrive between November and December. The female A. australis presents a seasonal monoestric reproductive cycle. Gestation lasts for 12 months and the females show estrous signs one week after parturition (Vaz-Ferreira 1976). The exact estrus length is not known.

There are controversies in the literature about the age at which males reach sexual maturity; some authors agree that a 5-year-old male is already adult (Andersen 1969), but other authors refer to the capability of establishing harems as an indicator of sexual maturity, and this feature is achieved at about 9 years of age (Atkinson 1997). In Ota- riidea both sexes may show morphological and physiological characteristics that guarantee successful reproduction and species perpetuation, for example, the long embryonic diapause that occurs in almost all species until up to five months after copulation (Berta et al. 2006) and selection pressure imposed by territorial disputes and copulation tactics (Gemmel et al. 2001).

Pinnipeds (seals, walrus, sea lions, and fur seals) live mainly in polar or sub-polar regions and present large environmental influence in their seasonal reproduction. Environmental factors such as photoperiod are related to the onset of estrus and the occurrence of delayed implantation in females (Temte 1985) and may also affect the rate of spermatogenesis in males (Sinha et al. 1977).

Reviews of anatomy and its relationship with biology and ecology have been recently published for some marine mammals (Reidenberg 2007, Uhen 2007). The relationship between morphology and seasonal functionality of the reproductive organs in the Otariidea family has been scientifically demonstrated (Colegrove et al. 2009a, Colegrove et al. 2009b). Based on the possibility that the anatomy of male genital organs relates to the environment and influences reproductive success and conservation status of the species, we hypothesize that special features found in the morphology of $A$. australis genital organs are related to the unique annual mating season. Under this focus, the present work describes the macroscopic and microscopic anatomy of the genital organs of young and adult male South American Fur Seals, identifying structures related to testicular temperature maintenance (thermo-regulatory mechanis$\mathrm{ms}$ ) or resistance to friction (mechanical features) that protect the external genitals organs, the scrotum and penis.

\section{MATERIALS AND METHODS}

The fur seal specimens originated from the reproductive colony of Cabo Polonio, Uruguay ( $34^{\circ} 23^{\prime} 60$ S; 53 46’ 60 W). Samples were collected and transported under license (CITES 000735) from the Faculty of Veterinary Medicine and Animal Sciences, University of São Paulo, São Paulo, Brazil and the civil organization Protección de la Fauna Marina, Uruguay (License 8889-169/17), authorized by the Uruguay government, Dirección Nacional de Recursos Acuáticos, Uruguay. Seven male South American Fur Seals, dead by natural causes (male rivalry, environmental conditions) or anthropic pressure unrelated to this research (i.e., entrapment in fishing nets, intentional killing by fishermen) in July 2005 and May 2006, were collected and measured as described by the Instituto Brasileiro do Meio Ambiente e dos Recursos Naturais Renováveis - IBAMA (IBAMA 2001) and Scheffer (1967).

The five young and two adult animals had their abdominal cavity opened and through cathetering of aorta abdominalis, caudally to the arteria renalis, were fixed by infusion with $4 \%$ paraformaldehyde solution. After complete tissue fixation, the entire genital tract was removed after opening the symphysis pelvica. The reproductive tract was dissected to observe the macroscopic characteristics. The resulting exposed morphology was recorded by measuring, photographing, and drawing the various organs. Measurements of the genital organs were correlated with the different ages of animals studied using the length of the organ multiplied by the body length / 100 (in centimeters), as is presented in Table 1.

For microscopic study, each genital organ was divided into 
Table 1. Body length of young and adult animals Arctocephalus australis and the percentage length of structures to its whole body

\begin{tabular}{|c|c|c|c|c|c|c|c|c|c|c|c|}
\hline \multirow[t]{2}{*}{ Animals } & \multirow{2}{*}{$\begin{array}{l}\text { Total } \\
\text { length }\end{array}$} & \multicolumn{3}{|c|}{ Anterior limb** } & \multicolumn{3}{|c|}{ Posterior limb** } & \multirow[t]{2}{*}{ Ax.circumf. } & \multirow[t]{2}{*}{ Testis } & \multirow[t]{2}{*}{ Penis } & \multirow[t]{2}{*}{ Urethra } \\
\hline & & Anterior & Posterio & r Width & Anterio & Posterior & Width & & & & \\
\hline Young5 & 98 & 29 & 11 & 10 & 23 & 22 & 10 & 51 & 2.8 & 7.8 & 12.6 \\
\hline Young6 & 86 & 27 & 11 & 10 & 20 & 19 & 8 & 51 & 2.8 & 7.6 & 11.8 \\
\hline Young7 & 74 & 23 & 10 & 9 & 17 & 17 & 6 & 51 & 2.3 & 7.5 & 12 \\
\hline Young11 & 94 & 32 & 11 & 10.5 & 23 & 21 & 8.5 & 53 & 2.9 & 7.8 & 12.8 \\
\hline Young13 & 81 & 26 & 11 & 9.5 & 21 & 21 & 9.5 & 54 & 2.4 & 7.3 & 11.3 \\
\hline Mean & 86.6 & 27.4 & 10.8 & 9.8 & 20.8 & 20 & 8.4 & 52 & $2.64( \pm 3 \%)^{*}$ & $7.6( \pm 8 \%)^{*}$ & $12.1( \pm 13 \%)^{*}$ \\
\hline Adult1 & 168 & 50 & 17 & 19 & 39 & 35 & 14 & 90 & 7 & 23.5 & 30 \\
\hline Adult2 & 156 & 45 & 15.5 & 16 & 35 & 34 & 13 & 80 & 5.5 & 21 & 29 \\
\hline Mean & 162 & 47.50 & 16.25 & 17.5 & 37 & 34.50 & 13.5 & 85 & $6.25( \pm 4 \%)^{*}$ & $22.3( \pm 14 \%)^{*}$ & $29.5( \pm 18 \%)^{*}$ \\
\hline
\end{tabular}

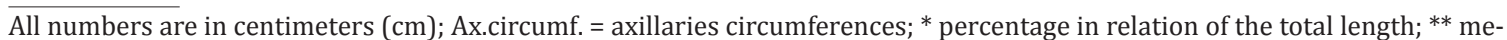
asurements of Anterior and Posterior limbs according to IBAMA (2001).

three parts (cranial, middle, and caudal) and three samples were collected from each part. From the penis three samples were collected from the radix, from the corpus, from the glans, and from the os penis. Samples $\left(0.5 \mathrm{~cm}^{3}\right)$ of genital organs were post-fixed by immersion in $4 \%$ paraformaldehyde solution. Samples were dehydrated in a graded series of ethanol (70 to 100\%). Dehydrated samples completed conventional processing for inclusion in Paraplast $^{\circledR}$ (Leica, Wetzler, Hessen, Germany).

Tissues were cut into $5 \mu \mathrm{m}$ slices and placed on APES (SIGMA-Aldrich, Deisenhofen, Bayern, Germany) treated slides. After deparaffinization, tissue slices on slides were stained with hematoxylin/eosin, Masson's trichrome, aldehyde/fuchsin, or picrosirius staining protocols. Microscopic anatomy was evaluated and photomicrographed using an Olympus BX 60 microscope connected to an Axio CAM HRc camera. Images were recorded using the Zeiss (Goettingen, Lower Saxony, Germany) KS 400 software.

Samples $\left(1 \mathrm{~cm}^{3}\right)$ from the distal third (corona) of the glans penis of three young and one adult animal (1 sample/animal) were collected for scanning electronic microscopy. Samples were post-fixed in $2.5 \%$ phosphate buffered glutaraldehyde solution $(0.1 \mathrm{M}$, $\mathrm{pH} 7.4$ ) for $24 \mathrm{~h}$. Post-fixation continued in 1\% osmium tetroxide (90 minutes) and 1\% tannic acid (60 minutes). Samples were dehydrated in a graded series of ethanol (70 to $100 \%$ ) and subsequently dried in a critical point dryer (Balzers Union - CPD 020). Each fragment was glued onto a stub and sputter-coated with gold using an Emitech K550 (Emitech Products Inc., Houston, USA). Coated specimens were viewed under scanning electron microscope LEO 435 VP (Leo Electron Microscopy, Cambridge, UK).

The two superior canine teeth of each animal were collected for age determination. The canine teeth were macerated in water for 90 days to removal organics debris. The left canine teeth of the all animals and the os penis of the three young animals and one adult animal were decalcified for microscopic analysis. Morse solution (Kiviranta et al. 1980) was used for slow decalcification of canine teeth and the os penis. Os penis samples were decalcified for 60 and teeth for 90 days, embedded in Paraplast $t^{\circledR}$, and processed like smooth tissue probes.

The age of the animals was determined using two different techniques: Dentine Growth Layers counting (GLDs) and Dentine external Ring Deposition (DRD) observation. Teeth were cut manually using the blade of a microtome Leica 818 (Leica Biosystems GmbH, Nussloch, Germany) and then brushed with powdered graphite, to increase the contrast between the GLDs, as described by Schiller (2000). The samples were photomicrographed at $40 \mathrm{x}$ for counting of growth layers of the dentine (GLDs). The right superior canine teeth, macerated in water, were photographed at a distance of about $10 \mathrm{~cm}$ and had their DRD counted.

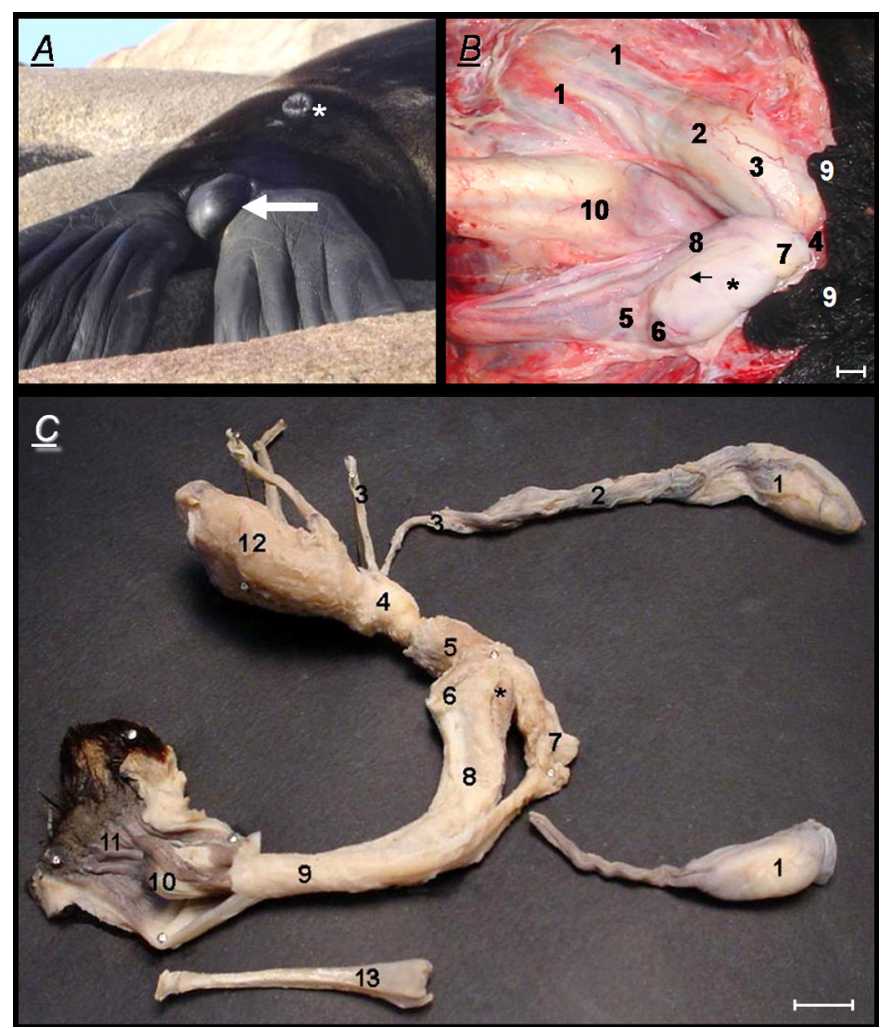

Fig.1. Gross anatomy of genital organs of the male South American Fur Seal. (A) Adult male life, lying on the back, pendulous scrotum (arrow) and the skin fold of prepuce $(*)$. (B) In-situ preparation of inguinal region of adult male sexual organs, viewed from the ventral side (Bar: $1 \mathrm{~cm})$. The left vaginal process is unopened (above), the right one (below) is fenestrated. 1 - Cremaster muscle (two lateral bundles). 2 - Parietal vaginal tunic showing some vascularization (3). 4 - Ligament of epididymal tail caudally being attached to the scrotum $(9$, with black scrotal skin). 5 - Pampiniform plexus and right testicular artery which ramifies on the surface of testis (arrow). Head (6) and tail (7) of epididymis. 8 - Ductus deferens. 10 - Radix Penis (in the background). (C) Overview of dissected young male reproductive organs (Bar: $1 \mathrm{~cm}) .1$ - Testes (the left one cut and positioned at lower right). 2 - Funiculus spermaticus. 3 - Ductus deferens. 4 - Prostate. 5 - Pelvic urethra. 6 - Radix Penis . 7 - Retractor penis muscle. 8 - Corpus penis. 9 - Glans penis: pars longa glandis. 10 - Corona glandis. 11 - Prepuce. 12 - Urinary bladder. 13 - Os penis (macerated preparation from another animal). * Bulbus penis. 


\section{RESULTS}

The genital organs include the scrotum, testis, epididymis, funiculus spermaticus, prostate, and penis with prepuce (Fig.1A-C).

The pendulous scrotum was black with a few primary hairs and was divided by a septum, as observed in live animals sleeping over stones (Fig.1A). In dead animals the testicles were not in the scrotum, but pre-scrotal in localization. A overview of dissected young male showing testes, funiculus spermaticus, ductus deferens, prostate, pelvic urethra, penis, retractor penis muscle, corpus penis with bulbus penis, glans penis, pars longa glandis, corona glandis, prepuce, and os penis is presented in Fig.1C.
Microscopically we observed that scrotal skin had a thick stratum corneum but a thin dermis. The epidermis was keratinized stratified cells (Epitheliocytus squamosus), with typical hexagonal cells in the stratum corneum, cuboidal cells in stratum spinosum (Epitheliocytus spinosus) and basale (Epitheliocytus basalis), and Melanocytus in the stratum basale. Other layers were not present in the epithelium. A basal membrane supported the epithelium and separated it from the dermis, as demonstrated in high magnification (Fig.2A). The dermis was divided into stratum papillare and stratum reticulare. The stratum papillare was characterized by loose connective tissue. The stratum reticulare was characterized by dense irregular connective

Fig.2. Scrotum, testis, epididymis and deferent duct of the South American Fur Seal. (A) Integumental histology of scrotum: Hematoxylin/eosin (HE) staining (Bar: $12 \mu \mathrm{m}$ ). E - Epidermis: B - Stratum basale with magnification in inset (Bar: $20 \mu \mathrm{m}$ ). Basal keratinocytes and melanocytus (M). S - Stratum spinosum. C - Stratum corneum, BM - basal membrane, blood vessels (Ve). (B) Integumental histology of scrotum: Masson trichrome staining (Bar: $75 \mu \mathrm{m}$ ). Arrows - Scrotal epithelium. F - Hair follicles. SG - Sebaceous gland. SW - Sweat glands. TD - Tunica dartos with strands of smooth muscle. (C) Longitudinally sectioned distal part of vaginal process of young animal enclosing the vaginal cavity with parietal (arrow) and visceral (arrowhead) vaginal tunic (Bar: $0.5 \mathrm{~cm}$ ). Parenchyma testis (P), the epididymis - by section visible as head $(\mathrm{H})$ and tail $(\mathrm{T})$, pampiniform plexus (PP) which is the distal part of funiculus spermaticus (extreme top). (D) Histological section of testicular tunica albuginea: Tri-

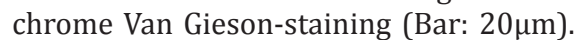
Collagen fibers (red), elastic fibers (arrows). A ramus of testicular artery (TA) . TP - Testicular parenchyma. (E) Seminiferous tubule of young animal: HE staining (Bar: $20 \mu \mathrm{m})$. SG - Spermatogonia. PS - Primary spermatocytes. Intertubular stroma with Leydig cells (note the scarce number) (L) and myofibrocites (M). (F) Seminiferous tubule of adult animal: HE staining (Bar: $12 \mu \mathrm{m})$. (L) Leydig cells. (M) Myofibrocites. S - Sertoli cells. SG - Spermatogonia. PS Primary spermatocytes. SP - Spermatides. (G) Overview histological section of adult epididymal tail (Bar: $30 \mu \mathrm{m}$ ). By Masson trichrome staining. Connective tissue (arrows), muscular layer (M), pseudostratified columnar epithelium (E). Small quantity of spermatozoa (arrowheads). (H) High-columnar pseudostratified epithelium of epididymal duct: HE staining

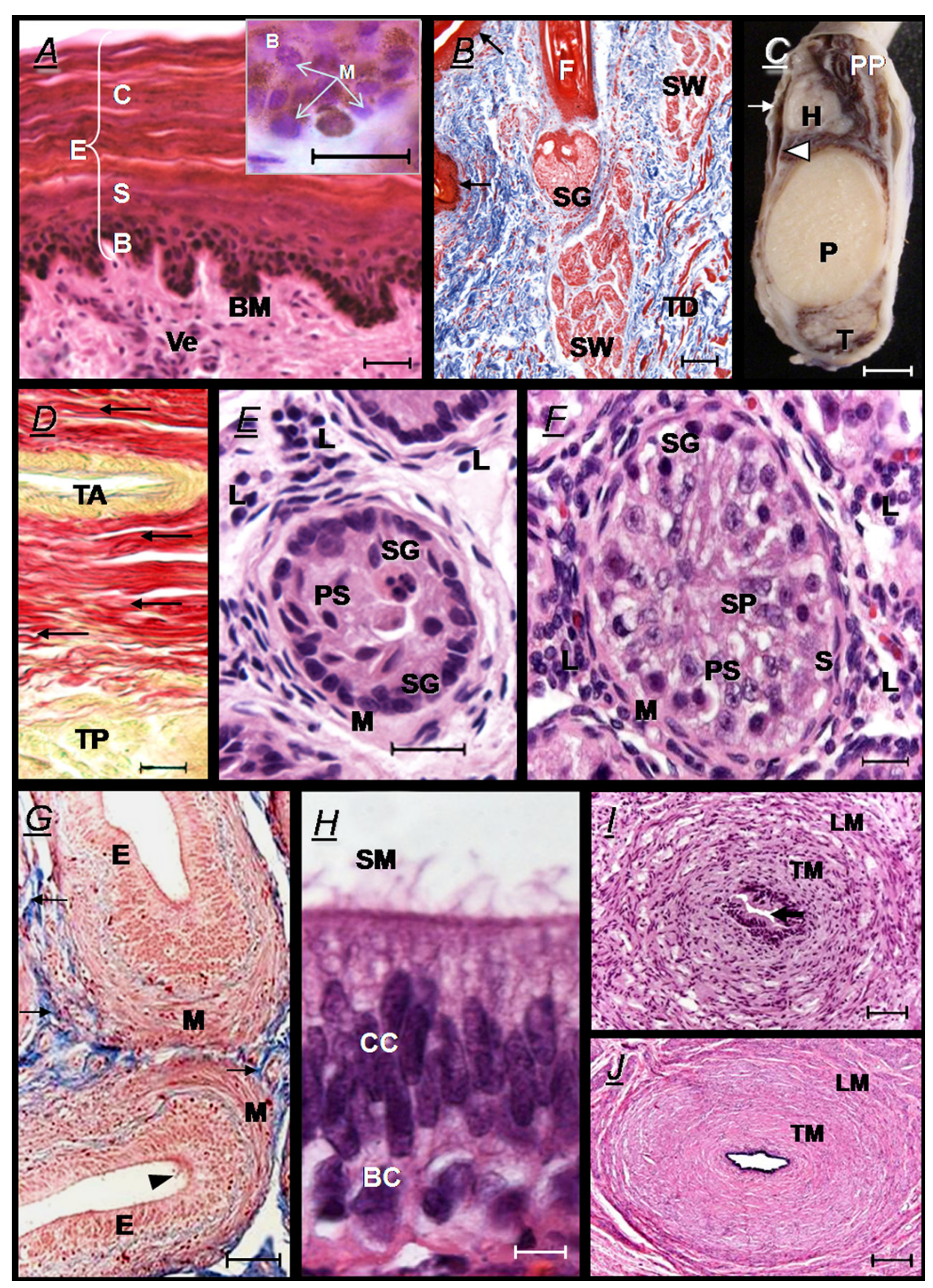
(Bar: $15 \mu \mathrm{m}$ ). BC - Basal cells. C -) Columnar cells with stereociliated microvilli (SM). (I) Histological section of the final part of the young deferent duct showing non-glandular parts and absence of glandula ampullae (Bar: $55 \mu \mathrm{m}$ ). TM - Transversal muscle layer. LM - Longitudinal muscle layer, pleated lumen (arrow). (J) Histological section of the final part of the adult deferent duct showing non-glandular part and absence of glandula ampullae (Bar: $200 \mu \mathrm{m})$. TM - Transversal muscle layer. LM - Longitudinal muscle layer. 
tissue. Adjacent to the dermis, the subcutis was composed of dense irregular connective tissue. The tunica dartos, consisting of a thick layer of smooth muscle fibers, was localized just beneath the dermis. Sweat and sebaceous glands were scant and found only within the scarce hair follicles (Fig.2B).

\section{Testes}

Macroscopically, Arctocephalus australis testes are oval parenchymatous organs (Fig.2C). Their length represented $3 \%$ of corporal length in young and $4 \%$ in adult animals (Table 1). All studied seal cadavers presented the left testis cranial to the right one. The testes are covered by the parietal and visceral vaginal tunics. The visceral layer covers the testes, epididymis, and the caudal region of the funiculus spermaticus, containing the pampiniform plexus (Fig.2C). The cremaster muscle is situated externally to the parietal layer. It is constituted by two lateral bundles, from the anulus vaginalis, whose fibers are inserted in the caudal portion of the tunica vaginalis (Fig.1B).

Microscopically, the tunica albuginea is composed of dense connective tissue rich in collagen and elastic fibers, as well as capillaries from the testicular artery (tunica vasculosa, Fig.2D). The septula testis, presenting the same constitution as the tunica albuginea, are continuous with the intertubular connective tissue and converge at the mediastinum testes dividing the parenchyma in several lobuli testis, as visualized in our sections.

Intertubular spaces contain blood vessels, fibrocytes, and Leydig cells that show irregular and polyhedral shape, as well as spherical nuclei containing concentrated chromatin (Fig.2E, F). In the young animals the cells in the intertubular space are less numerous and more easily distinguished than in the adults (Fig.2E,F).

Convoluted seminiferous tubules are observed in the parenchyma testis and surrounded by a peritubular tunic of contractile cells, the myofibrocytes. These tubules are tortuous and show a spermatogenic epithelium constituted by Sertoli and spermatic cells (Fig.2E,F). Spermatogonia A are the most abundant cells in young animals. On the other hand, adult animals show scarce spermatocytes or spermatozoa in the lumen of convoluted seminiferous tubules in winter (Fig.2F).

\section{Epididymis}

The epididymis has the same appearance found in terrestrial mammals and is macroscopically divided into three regions: head, body, and tail. The head is situated in the cranial portion of the testis and constitutes the origin of the ductus epididymidis. The body is the longest and thinnest part of this organ while the tail is the final portion of the ductus epididymidis and the origin of the ductus deferens, fixed to the testis caudal region by the ligamentum testis proprium.

The epididymis is constituted by a single and extremely coiled duct. Histologically, it presents a mucous membrane covered by a pseudostratified columnar epithelium. This epithelium is sustained by a lamina propria characterized by loose connective tissue rich in vessels, collagen, and muscular fibers along its length. The muscular layer becomes thicker from the head toward the tail of the epididymis. No spermatozoa were observed in young animals. Examinations in adult animals showed a small quantity of spermatozoa in the tail of the epididymis (Fig.2G). Epididymal duct epithelium presents basal cells and superficial columnar cells. Superficial columnar cells present a prismatic form, lipid droplets, evident apical and cytoplasmic stereociliated specializations, transversal and longitudinal muscular layers, and pleated lumen (Fig.2H).

Histological section of the final part of the five young and two adult deferent ducts shows a non-glandular portion and absence of glandula ampullae in this species at both right and left sides (Fig.2I, J). The end part of the deferent ducts is surrounded by the prostate (Fig.3Bi).

\section{Prostate}

The prostate has two parts: corpus and pars disseminata. It lies around the urethra, caudal to the trigonum vesicae and cranially to the urethra pars pelvina. It is composed by a single spherical lobe (Fig.3A).

Microscopically, a capsule of dense irregular connective tissue surrounds the prostate and emits large trabeculae dividing the pars disseminata in individual lobules. It shows numerous small excretory ducts, which open into the urethral lumen (Fig.3Cii). The secretory tubules of the prostate show simple cuboidal epithelium. The colliculum seminalis, situated in ventral portion in the lumen of the prostatic urethra, presents the ostium ejaculatorium in its centromedial portion (Fig.3Cii). The corpus prostatae is surrounded by a muscular layer provided by the urethral muscle, which in turn surrounds the pars disseminata prostatae (Fig.3Diii).

The penis of the fur seal has four parts: radix, corpus, glans, and os penis (Fig.3E). Penile length was $8 \%$ of the body length in the younger animals and $14 \%$ in the adult animals. Penises were classified, according to the observed morphology, as belonging to the vascular type formed by two crura penis and a urethra surrounded by the dense irregular connective tissue of the tunica albuginea. The penis lies in a subcutaneous sheath.

The radix penis is attached to os ischii caudal borders. It presents the insertion of two crura penis and is covered by ischiocavernosus muscle and bulbus penis, which is surrounded by the bulbospongiosus muscle (Fig. 3F). The retractor penis muscle presents just the pars analis which arises from the external fascia of the external anal sphincter muscle. The ligamentum suspensorium penis covers the dorsal vessels and nerves of the organ, extending from the symphysis pelvina to the corpus cavernosus (Fig.3F). The bulbus penis of $A$. australis lies ventrally to the radix penis and is covered by the bulbospongiosus muscle (Fig.1C*).

Microscopically, the radix penis is constituted by dense connective tissue rich in collagen fibers and covered by fibers of the ischiocavernosus and bulbospongiosus muscles (Fig.3G). The corpus penis extends from the radix until the glans penis and corresponds to about $50 \%$ of the total penis length with measurement immediately pos dissection (Fig.3E, tissues post-fixed by immersion in 4\% paraformal- 


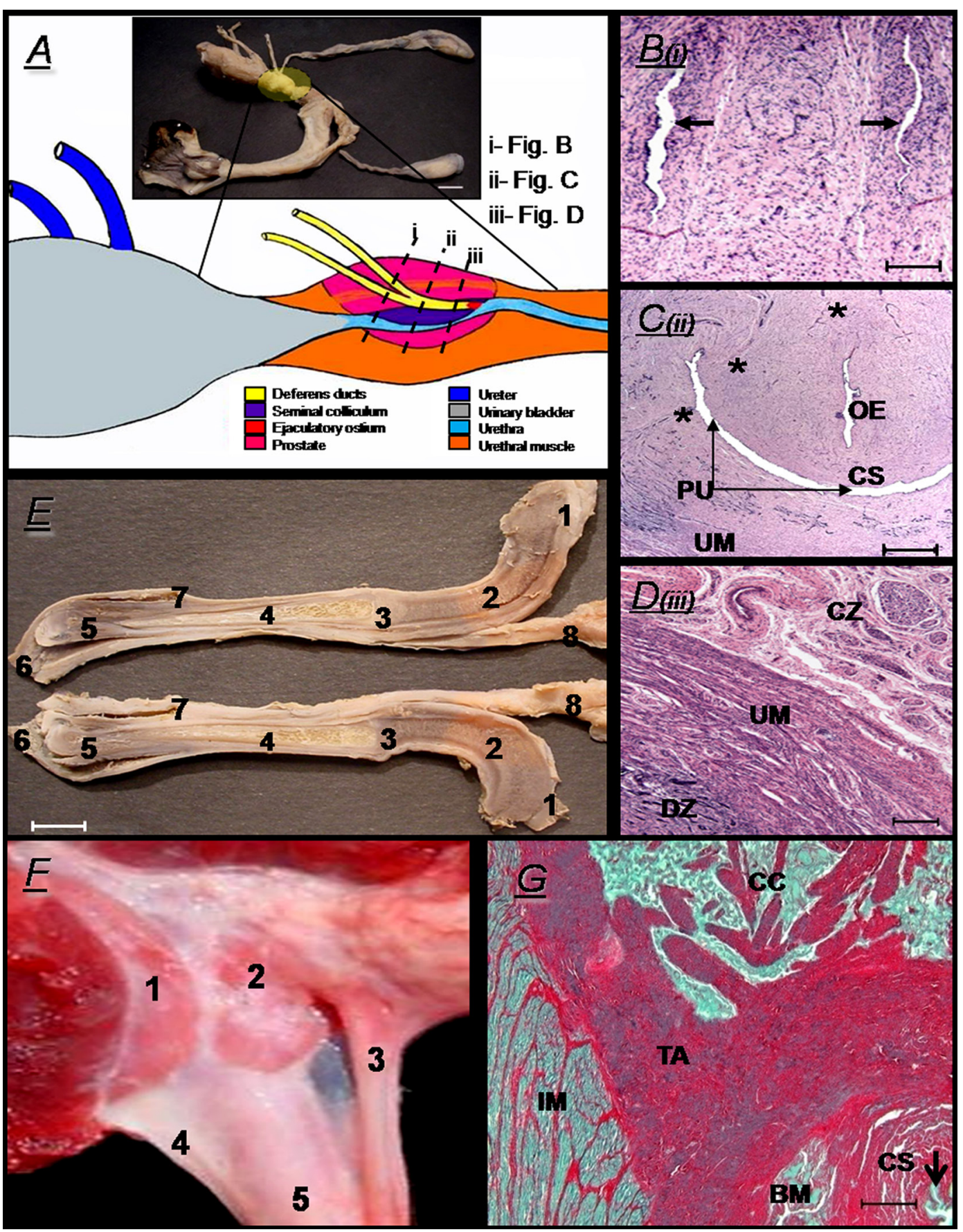

Fig.3. Prostate and penis of the South American fur seal. (A) Schematic drawing of prostatic region of the Arctocephalus australis, showing the arrival of deferent ducts in the urethra. Sections in different regions of the prostate (Figures B(i), C(ii) and D(iii)), colliculum seminalis, ostium ejaculatorium, urethra, urethral muscle, and adjacent urinary structures are indicated. (Inset of macroscopy of male genital organs, Bar: $1 \mathrm{~cm}$ ). (B) Histology of the end part of deferent ducts involved by prostate, HE staining (Bar: $170 \mu \mathrm{m}$ ). Two ductal lumens (arrows). (C) Histological overview of the colliculum seminalis (C ) region: HE staining (Bar: $500 \mu \mathrm{m}$ ). OE - Ostium ejaculatorium. PU - Prostatic urethra.

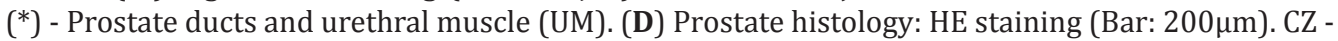
Corporal zone. UM - Urethral muscle. DZ- Disseminate zone of prostate. (E) Longitudinally sectioned penis of young animal (Bar: $1 \mathrm{~cm}$ ). 1 - Bulbus penis. 2 - Corpus penis. 3 - Bulbus glandis. 4 - Os penis. 5 - Corona glandis. 6 - Prepuce. 7 - Fundus of prepucial cavity. 8 - Retractor penis (smooth) muscle. (F) Photography of lateral view of the radix penis: 1 - Ischiocavernosus muscle. 2- Bulbospongiosus muscle. 3 - Retractor penis muscle. 4 - Ligamentum suspensorium penis. 5 - Corpus penis. (G) Overview histological section of radix penis: Picrosirius staining (Bar: $500 \mu \mathrm{m})$. Corpus cavernosus (CC, fibrocavernous type), and corpus spongiosus of bulbus penis (CS), tunica albuginea of penis (TA). IM - Ischiocavernosus muscle. BM - Bulbospongiosus muscle. Arrow - Urethra. 
dehyde solution). It is a portion with erectile capacity, constituted by corpus cavernosus and corpus spongiosum of the penile urethra. Paired retractor penis muscles overlay the urethra. No elastic fibers are found in the tunica albuginea. The corpus cavernosum (fibrocavernous type), is constituted by collagen and elastic fibers as well as smooth muscle. The erectile tissue is rich in arterioles, morphologically and topographically identified as arteries helicine, which end in the cavernosum sinus.

The glans penis can be divided into bulbus glandis, pars longa glandis, and corona glandis. The bulbus glandis is the distal end of the corpus penis, and presents capacity of expansion from erectile tissue. It is constituted by corpus cavernosum and corpus spongiosum ossified (os penis) covered by the tunica albuginea (Fig.3E).

The pars longa glandis is the longest portion of the glans, and presents the smallest diameter among other glans structures. Its erectile tissue (corpus spongiosus) is firmly attached to the os penis.

The corona glandis is the distal portion of the penis and shows a singular morphology. The os penis is situated centrally to the corona and is surrounded by a slim layer of corpus spongiosum and mucosa. Around this central projection (protuberance of the os penis) there is a free border of erectile tissue, scarcely pigmented, unfastened from the protuberance of the os penis, imparting the appearance of a lily flower to the corona glandis (lily-form). In young animals the os penis is projected distally, arriving at the apex of the penis, but the free border is less evident than in adults (Fig.4A,B).

The free border of the corona glandis is covered by non-keratinized stratified squamous epithelium with deep epidermal papillae inserting into the dermis (Fig.4C). We suggest the anatomical name margo petaliformis for this particular arrangement of the free border of the corona glandis. Scanning electron microscopy (SEM) showed strong similarity of the morphology of the corona glandis in the two studied ages (Fig.4D,E). We observed in SEM that the degree of epithelial cell desquamation in corona glandis is greater in the adult animal than in the young animal. In all studied animals, greater vascularization was observed in corpus spongiosum glandis of the margo petaliformis, related to the erectile capacity of this region (Fig.4F).

The os penis is part of the visceral skeleton in this species. Its origin lies at the bulbus glandis distal portion and it reaches the distal portion of the corona glandis. It shows a triangular form, with its base corresponding to the ventral portion. Dilatations in its cranial and caudal extremities are observed. The diameter of the caudal extremity is bigger than the cranial one (Fig.1C). The os penis shows a slight ventral depression for the urethral insertion, although no groove can be characterized (Fig.4G).

Microscopically, it is an endochondral bone with a cortical compact zone and a medullary zone filled with trabecular bone surrounded by fat cells (Fig.4G,H).

The prepuce is located externally, in the region between the umbilical scar and the scrotum (Fig.1A). Macroscopically, a sphincter is observed around the ostium preputiale. The prepuce is composed of an external lamina covered by black skin and an internal non-pigmented one close to the penis mucosa. The internal lamina of the prepuce is retractile and covers the glans penis (Fig.4A,B). The external lamina shows a keratinized stratified pavimentous epithelium. The dermis is composed of dense connective tissue with sebaceous and sweat glands. The internal lamina of the prepuce presents non-keratinized stratified pavimentous epithelium lacking hairs and glands. Great amounts of vessels, nerves, and smooth muscle in circular orientation are observed in this region (Fig.4I).

\section{Age determination}

The GLDs and DRD methods provided consistent results in estimating individual ages (Table 1). According to these methods of the age determination, the young animals are 1 year old and the adult animals are 5 years old.

\section{Measurements}

The lengths of the genital organs and their relation to body length are presented in percentage form in Table 1.

\section{DISCUSSION}

Among the studied characteristics, those related to morphologic evolution, copulatory strategies, thermo-regulatory and mechanical protection mechanisms, as well as the differences between young and adult animals are discussed here. These are considered the most relevant anatomical structures and may sustain future research on reproductive physiology of the species.

The presence of the scrotum is one of the characteristics that enables the classification of Arctocephalus australis within the Otariidea family (King 1983), as opposed to the Phocidea, in which the scrotum has disappeared (Werdelin \&Nilsonne 1999).

The studied adult animals exhibit testicular stroma morphology compatible with steroidogenic activity due to the high concentration of the Leydig cells, aromatase expression (Machado 2006), and evident secondary sexual characteristics (Mendis-Handagama \& Siril-Ariyaratne 2005). The finding of primary spermatocytes and spermatozoa could suggest a recrudescent period, indicative of spermatogenesis seasonality (Singh \& Bharadwaj 1978) as observed in many pinnipeds including Hawaiian monk seals (Monachus schauinslandi) (Atkinson \& Gilmartin 1992) and harbor seals (Phoca vitulina) (Gardiner et al. 1999). We did not find normal spermatogenesis in winter, 5 months before the next mating season. This may suggests that an azosperm period can occur in this species several months after the reproductive period, although this fact is not yet completely elucidated in A. australis (Ridgway \& Harrison 1993). The difficulty of obtaining samples in winter, when the adult males are usually far from their reproductive colony, has impaired more complex studies to answer this question.

The presence of the glandular portion of the end part of the deferent duct in the male genital organs varies from species to species. For instance, in bulls the glandular portion of the end part of the deferent duct is a large structure easily identifiable able to store spermatozoa for several 


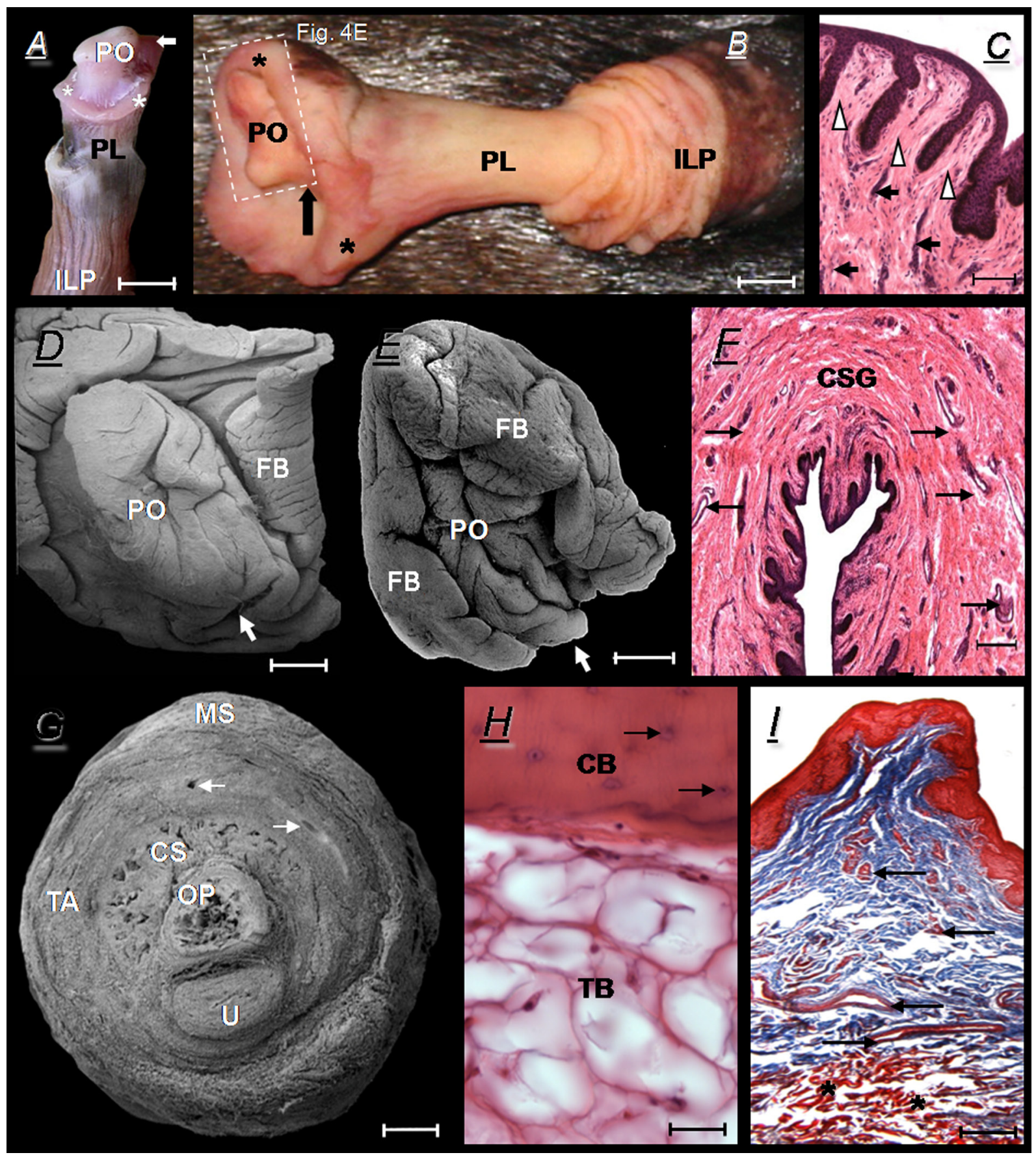

Fig.4. Glans penis, os penis and prepuce of the South American fur seal. (A) Glans penis of young animal (Bar: $0.75 \mathrm{~cm})$ : (PL) Pars longa glandis. (ILP) Internal lamina of the prepuce. (PO) Protuberance of the os penis. $\left(^{*}\right)$ Free border of corona glandis (margo petaliformis). (Arrow) Location of external urethral opening. (B) Glans penis and retracted prepuce of adult animal (Bar: $1.25 \mathrm{~cm}$ ): PL - Pars longa glandis. ILP - Internal non-pigmented lamina of prepuce. PO - Protuberance of the os penis. * Margo petaliformis. Arrow - External urethral opening. (C) Histological cross section of margo petaliformis of adult animals: HE staining (Bar: $200 \mu \mathrm{m}$ ). Arrows - Veins mark the corpus spongiosum glandis. Arrowheads - Deep epidermal papillae. (D) Scanning electron microscopy (SEM) of corona glandis, young animal (Bar: 0.75mm). MP - Margo petaliformis. PO - Distal portion of the os penis covered by spongious tissue. Arrow - Urethral opening. (E) SEM of top of corona glandis, adult male (Bar: 1mm). MP- Margo petaliformis. PO - Protuberance of the os penis. Arrow - Urethral opening. (F) Histology of margo petaliformis lateral view of an young animal (Bar: $200 \mu \mathrm{m}$ ). (Arrows) Tissue with numerous vessels, CSG - Corpus spongiosum glandis. (G) SEM of transversal section through the pars longa glandis region of young animal (Bar: 1mm). M -) Mucosal surface. Arrows - Dorsal vessels of penis. OP - Os penis. CS - Corpus spongiosus glandis. A -) Albuginea tunic. U - Urethra. (H) Decalcified os penis (Bar: $40 \mu \mathrm{m}$ ). (CB) Cortical bone, osteocytes showed by arrows. TB - Trabecular bone with fat cells. (I) Histology of prepuce internal lamina, Masson trichrome staining (Bar: $150 \mu \mathrm{m}$ ). Note the absence of the hair follicles in the mucosal integument. Arrows - Blood vessels and smooth muscle $\left(^{*}\right)$ of the sphincter of the prepuce. 
days before ejaculation (Matousek \& Klaudy 1998), while the organ is small in dogs, with minimal relevance in anatomical studies (Davidson \& Baker 2009) and does not exist in cats (Knobil et al. 2006). The function of the glandular portion of the end part of the deferent duct has not yet been fully elucidated. Its fluid adds species-specific proteins and hormone to seminal fluid, known to associate with the sperm surface and participate in the complex events of sperm-egg interaction (Schambony et al. 1998). Glutathione peroxidase and superoxide dismutase enzymes, as well as antioxidant substances and secretory proteins rich in cysteine, were found in the secretion of the glandular portion of the end part of the deferent duct by Barber \& Ball (2005). The absence of an ampulla and its glands in our samples during the non-breeding season may be related to spermatogenesis seasonality as in other pinnipeds (Ridgway \& Harrison 1993) and may reflect adaptations of the reproductive accessory glands to achieve reproductive success - in contrast with carnivorous non-seasonal breeders such as the dog (Schaller \& Constantinescu 1999, Nickel et al. 1979). Further studies are necessary to access levels of spermatozoon oxidation and events of sperm-egg interaction in A. australis, functions related with this reproductive accessory gland.

A. australis colliculus seminalis presents a large size in comparison with the lumen of the prostatic urethra. The ejaculatory orifice (ostium ejaculatorium) is situated in the caudal face of the colliculus seminalis, which supports the hypothesis that the urethral cavernous reflex may occur in this species (Shafik 2005).

The penis size has been described as bigger in polygamic than in monogamic species (Dahl 1994). A. australis is a polygamic species, and does belong to the group of animals that show large penis size. Penis size has been related to postcopulatory sexual selection (Birkhead \& Moller 1998). According to this theory, the site of ejaculation is the object of selection, which favored the male with bigger penis to deposit sperm closer to the egg, which is important for polygamous species and of little relevance in monogamous species. This has been demonstrated for several species, and the os penis assisting in copula and place of ejaculation may act as a decisive factor in the rate of paternity (Ramm 2007). The dog, to which the penis of $A$. australis is most similar, is described as being a promiscuous breeder (Beaver 2009), although some seals are definitely monogamic (Berta et al. 2006). Studies measuring length of male genital organs usually correlate length of penis (mm) with body weight (kg) (Dahl 1994), but due to lack of infrastructure and equipment compatible with the size of these animals, as well as absence of specific reference, we used the length of penis $(\mathrm{cm})$ multiplied by body length $(\mathrm{cm}) / 100$ (Table 1$)$.

Penis structure in $A$. australis presents the same basic structure (radix, corpus, and glans) as proposed for the dog and many others species (Schaller and Constantinescu 1999, Nickel et al. 1979).

The radix penis has been related with functional mechanisms such as the penis attachment to the arcus ischiadicus and caudal border of the symphysis pelvina, as well as the induction and maintenance of penis erection (Merrick et al.
2002). Ventral penis innervations and vessels are located below the suspensory ligament, which attaches the radix penis to the border of the arcus ischiadicus. In the A. australis the radix penis is strong, characterized by dense connective tissue and numerous collagen fibers, this structure supporting the insertion of the two crura penis. The crura penis, fused and covered by ischiocavernosus muscle, are attached in the arcus ischiadicus. Conversely, in the dog, penis pillars are inserted separately at both sides of the arcus ischiadicus and join at the level of the radix penis (Howard \& George 1979).

The bulbus penis of $A$. australis, which lies ventrally to the radix penis, represents an anatomical difference in comparison with other species of carnivores. In dogs, for example, the bulbus penis lies caudo-dorsally to the radix penis (Christensen 1954, Howard \& George 1979). The different origin of the crura penis probably contributes to the difference in position of the bulbus penis observed between these two species.

According to Christensen (1954) the absence of elastic fibers in the albuginea tunic of the corpus penis is indicative of erection maintenance by increased blood pressure in this region. We observed a similar histological pattern in the tunica albuginea of $A$. australis, suggesting that the same mechanism also occurs in this species.

In dogs, the bulbus glandis is related to the maintenance of the copulatory lock by mechanical restriction of the penis' exit from the vagina after ejaculation, followed by relaxation (Howard \& George 1979). Proportionally, the bulbus glandis in $A$. australis presents half of the size if compared to dogs and no copulatory lock during copulation has been described. In Otariidea the penis bulb is in general not well developed (Andersen 1969). However, more studies are necessary for ascertaining the bulbus glandis function in $A$. australis.

The corona glandis of $A$. australis represents a singular structure, not yet described in any species, from which the os penis projects itself distally, leading the external urethral ostium. The os penis is an important parameter in studies of the evolution of genital organs and sperm competition (Laws 1964, Dahl 1994, Ramm 2007). The ancestral origin of pinnipeds' os penis has been recently described by Rybczynski et al. (2009), pointing towards the importance of this structure in the maintenance of this monoestrous species, in the context of postcopulatory sexual selection (Birkhead \& Moller 1998).

The form of the erectile border found in this region resembles a petal formation (in recognition of which we suggest the name margo petaliformis). This structure, associated with the central projection (os penis covered by mucosa), gives a "lily-flower" form to the corona glandis. The petal form suggests that the A. australis penis presents morphological evolutive adaptations in order to suit its shape to the female reproductive system (Machado \& Papa 2008). More research is needed to establish the specific functional significance of this particular arrangement.

\section{Thermo-regulatory mechanisms}

The folding and dark color of the scrotum are characte- 
ristics related with the thermo-regulatory capacity of this tissue (Song \& Seo 2009), which is crucial for normal spermatogenesis (Setchell 1998). Folding and remarkable pigmentation of the scrotum of the A. australis may be related to testes thermo-regulation in the species, probably protecting the apocrine glands against lesion by ultraviolet radiation (Jablonski \& Chaplin 2000). Seasonal influence on scrotum color could not be determined from present data, but some reports focus on that point (Bubenik \& Bubenik 1985). Moreover, the high skin melanization offers further protection against pholate-photolysis, which is essential to spermatogenesis (Wilson \& Spaziani 1976). The thickness of the tunica dartos, responsible for the pleated appearance of the scrotum, influences spermatogenesis due to its importance in scrotal contraction as a control mechanism of the testicular temperature (Yilmaz et al. 2006). The processus vaginalis peritonei, which corresponds to the anatomical space between parietal and visceral layers of the tunica vaginalis (Nogueira et al. 1977), is very well vascularized and takes part in metabolic and thermo-regulatory processes (Wensing \& Colenbrander 1986), as described in men (Mihalache et al. 1996) as well as for domestic species (Nogueira et al. 1977, Nickel et al. 1979). There is a direct association of vaginal tunic with the cremaster muscle in A. australis as described also for bulls, dogs, equines, and other animals (Nickel et al. 1979). The strong cremaster muscular fibers attach to the vaginal tunic to approach or separate the testis to/from the scrotum, a maneuver that reduces the processus vaginalis peritonei size influencing the motion of the testis, which, associated with the blood circulation of the cremaster muscle, helps regulate the temperature of the testes (Anderson et al. 1988, Longui 2005).

Microscopically, the tunica albuginea is constituted by collagen fibers, less numerous elastic fibers, smooth muscle, and a high number of blood vessels. Veins and arteries of the tunica albuginea constitute a heat dissipation mechanism for the whole parenchyma testis (Heinze \& Ptak 1976). The peculiar elasticity and contractility could be involved in the transport of spermatozoa through the testis system between the mediastinum and epididymis (Qin \& Lung 2000). However, the relationship between this mechanism and the thermo-regulation is not yet elucidated.

Spermatozoa maturation and competence acquisition occur in the caput and body of the epididymis in domestic species (Glover \& Nicander 1971). Moreover, epididymal function is directly related to cooling capacity and temperature maintenance of testis parenchyma in relation to the whole body. In pigs, for example, the head, body, and tail of the epididymis show respectively temperatures about $2.5,1.5$, and $1.9^{\circ} \mathrm{C}$ lower than rectal temperature (Stone 1981). In A. australis there are a great number of vessels in the epididymal capsule and in the pampiniform plexus in all animals studied, which suggests a complex thermo-regulatory mechanism involving this organ, as described for other species (Clavert et al. 1980). In manatees (Trichechus manatus), reproductive tissues are protected against high temperatures through a superficial blood-cooling system, which sends cool blood to the deep venous plexus and epididymal capsule (Rommel et al. 2001).

\section{Mechanical protection}

The thick epidermal stratum corneum of $A$. australis scrotum enables the constant contact of the scrotum with the ground. Epidermis adherence to the dermis occurs through dermal papillae (Banks 1991), which were found in elevated number and depth, certainly due to the constant attrition the epidermis must go through. The stratum corneum of $A$. australis also presents a large number of keratinocytes in the stratum basale, probably involved with re-epithelization and healing of skin lesions (Patel et al. 2006, Smiley et al. 2006).

In the distal part of the penis and margo petaliformis, numerous dermal papillae deeply project to the dermis, reflecting the level of tissue adaptation to copulation friction (Banks 1991). Another indicator of tissue resistance observed in the penis distal region is the tissue folding constituted by spongiosus tissue (Banks 1991), as observed by electron scanning microscopy (Fig.4F).

The preputial cavity presents natural age-dependent bacterial flora, in a similar way as do eyes, mouth, skin, and female reproductive organs (Bowen et al. 1982). Excessive washes make an imbalance of saprophyte flora, constituting a main factor that leads to growth of pathogenic organisms (Fleiss et al. 1998). In this context, the sphincter prevents the entrance of sea water at high hydrostatic pressure during deep diving and excessive washing as the animal swims or moves on the ground.

\section{Differences between young and adult animals}

Qualitative analysis of Leydig cells in the testicular stroma reveals variability between adult and young animals. In the prepubertal testis of mammals, including humans, because of the low levels of androgens, Leydig cells are scarce and smaller (Abney 1999). The sexual dimorphism is already remarkable at the age of 2 in A. australis, although secondary sexual characteristics remain undifferentiated until 7 to 9 years of age (Pereira 2005). In the Northern fur seal (Callorhinus ursinus), male sexual maturity and dimorphism are completed at 7 years of age (Browne et al. 2006). Based on our findings, we propose that $A$. australis already presents features compatible with sexual maturity at 5 years of age. Testis size presents a small difference between young ( $3 \%$ of the total length) and adult ( $4 \%$ of the total length) animals. In general, testis size does increase according to increasing body size. The ratio in many species is expected to be $3: 4$, with daily sperm production rate (Moller 1989) presenting the same magnitude. According to Table 1 the total length of the animals doubled between 1 and 5 years old, which did not occur to the testis length. The fact that the size of the testicle is proportionately lower in young animals may relate to the fact that adults animals described here are young adults (Cassini 1999) and probably are in azoospermy (Ashchepkova \& Fedoseev 1988). Perhaps the relationship of three fourths of growth in relation to body size in A. australis would hold true if the sample contained a higher number of animals older than 5 years old $(8,10,12$ years old, for example) and in reproductive season. A law (1956) concludes that puberty profoundly influences the relation between body and tes- 
tes growth. Sperm production rates and sperm reserves are therefore predicted to increase with increasing body size (Moller 1989).

In $A$. australis, the prostate shows features distinct from those described for humans (McNeal 1981): no pre-prostate region could be observed, but similarly to dogs (Chowning et al. 2006) there is a remarkable urethral lumen reduction in the proximity of the colliculus seminalis, into which numerous prostate ducts drain. Additionally, estrogen receptors (ER $\alpha$ and ER $\beta$ ) are present in the prostatic tissue, which respond to estradiol- $17 \beta$ direct stimulus influencing the development of this organ (Ellem and Risbridger 2006). We observed that the prostate in adult animals is more developed when compared to young ones, a fact that could be explained by adult hormonal stimulation (Table 1).

The difference in the proportional size of the penis between the young ( $\pm 8 \%$ of the body size) and adult animals ( $\pm 14 \%$ of the body size) may be related to the increase in the size of the penis and other genital organs after puberty, as seen for other pinnipeds species, probably determined by interactions between growth and gonadotrophic hormones of the anterior pituitary (Laws 1956).

The specialization of the corona glandis into the free border is already observed in the juvenile A. australis. The morphology of the corona glandis is very different among all described species and may represent an important aspect in the male competition to generate descendants (Dahl 1994).

\section{CONCLUSION}

The genital organs of the male Arctocephalus australis show some macroscopical and microscopical features that may be related to the evolutionary level of environmental adaptation. In general, the male genital organ morphology of $A$. australis reflects the anatomic description of other domestic and wild carnivores. As emphasized above, some features differ from other described males and are closely related to the biology and reproductive cycles of this species. Moreover, singular attention should be dedicated to the biological function of the margo petaliformis of the corona glandis. Regarding the conservation of the species, it is possible to perform morphological studies in A. australis reproductive colonies without killing animals, due to the frequency of natural death.

Acknowledgements.- This study was supported by CNPq and CAPES. We would like to thank Alberto Ponce de Leon and César Barreiro from DINARA (Dirección Nacional de Recursos Acuáticos) of Uruguay for their technical and logistic support. We would like to thank MV Rodolfo Pinho da Silva Filho (Neneco) from CRAM - Oceanographic Museu - FURG for all your support to the realization of this research.

\section{REFERENCES}

Abney T.0. 1999. The potential roles of estrogens in regulating Leydig cell development and function: A review. Steroids 64:610-617.

Andersen H.T. 1969. The biology of marine mammals. Academic Press, London, p.295-336.

Anderson G.L., Acland R.D., Siemionow M. \& Mccabe S.J. 1988. Vascular isolation of the rat cremaster muscle. Microvasc. Res. 36:56-63.
Ashchepkova L. \& Fedoseev V. 1988. Development of male germ cells in the fur seal (Callorhinus ursinus). Arkh. Anat. Histol. Embriol. 95:59-66.

Atkinson S. 1997. Reproductive biology of seals. Rev. Reprod. 2:175-194.

Atkinson S. \& Gilmartin W.G. 1992. Seasonal testosterone pattern in Hawaiian monk seals (Monachus schauinslandi). J. Reprod. Fertil. 96:35-39.

Banks J.W. 1991. Histologia Veterinária Aplicada. Manole, São Paulo. 629p.

Barber J. \& Ball B.A. 2005. Determination of glutathione peroxidase and superoxide dismutase-like activities in equine spermatozoa, seminal plasma, and reproductive tissues. Am. J. Vet. Res. 66:1415-1419.

Beaver B.V. 2009. Canine behavior: Insights and answers. $2^{\text {nd }}$ ed. W.B. Saunders, Missouri. 315p.

Berta A., Sumich J.L. \& Kovacs K.M. 2006. Marine Mammals: Evolutionary biology. $2^{\text {nd }}$ ed. Elsevier, California. 494p.

Birkhead T.R. \& Moller A.P. 1998. Sperm competition and sexual selection. Academic Press, London. 826p.

Bowen J.M., Tobin N., Simpson R.B., Lev W.B. \& Ansari M.M. 1982. Effects of washing on the bacterial flora of the stallion's penis. J. Reprod. Fert. (Suppl.)32:41-45.

Browne P., Conley A.J., Spraker T., Reamc R.R. \& Lasley B.L. 2006. Sex steroid concentrations and localization of steroidogenic enzyme expression in free-ranging female northern fur seals (Callorhinus ursinus). Gen. Comp. Endocrinol. 147:175-183.

Bubenik G.A. \& Bubenik A.B. 1985. Seasonal variations in hair pigmentation of white-tailed deer and their relationship to sexual activity and plasma testosterone. J. Exp. Zool. 235:387-395.

Cassini M.H. 1999. The evolution of reproductive systems in pinnipeds. Behav. Ecol. 10:612-616.

Chowning S.L., Susil R.C., Krieger A., Fichtinger G., Whitcomb L.L. \& Atalar E. 2006. A preliminary analysis and model of prostate injection distributions. Prostate 66:344-357.

Christensen G.C. 1954. Angioarchitecture of the canine penis and the process of erection. Am. J. Anat. 95:227-261.

Clavert A., Cranz C. \& Brun B. 1980. Study of the vascularization of the epididymis. Bull. Assoc. Anat. 64:539-546.

Colegrove K.M., Gulland F.M.D., Naydan D.K. \& Lowenstine L.J. 2009a. The normal genital tract of the female California sea lion (Zalophus californianus): Cyclic changes in histomorphology and hormone receptor distribution. Anat. Rec. 292:1801-1817.

Colegrove K.M., Gulland F.M.D., Naydan D.K. \& Lowenstine L.J. 2009b. Normal morphology and hormone receptor expression in the male California sea lion (Zalophus californianus) genital tract. Anat. Rec. 292:18181826.

Ellem S.J. \& Risbridger G.P. 2006. Aromatase and prostate cancer. Minerva Endocrinol. 31:1-12.

Dahl J.F. 1994. Size and form of the penis in orang-utans. J. Mammal. 75:1-9.

Davidson A.P. \& Baker T.W. 2009. Reproductive ultrasound of the dog and tom. Topics in Companion Animal Medicine 24:64-70.

Fleiss P.M., Hodges F.M. \& Van Howe R.S. 1998. Immunological functions of the human prepuce. Sex. Transm. Infect. 74:364-367.

Gardiner K.J., Boyd I.L., Follett B.K., Racey P.A. \& Reijnders P.J.H. 1999. Changes in pituitary, ovarian, and testicular activity in harbour seals (Phoca vitulina) in relation to season and sexual maturity. Can. J. Zool. 77:211-221.

Gemmell N.J., Burg T.M., Boyd I.L. \& Amos W. 2001. Low reproductive success in territorial male Antarctic fur seals (Arctocephalus gazella) suggests the existence of alternative mating strategies. Mol. Ecol. 10:451-460.

Glover T.D. \& Nicander L. 1971. Some aspects of structure and function in the mammalian epididymis. J. Reprod. Fertil. 13:39-50.

Heinze W. \& Ptak W. 1976. Comparative morphological studies on the vascular systems of testes in cattle, swine, horse and dog under functional conditions. Arch. Exp. Veterinärmed. 30:669-685.

Howard E.E. \& George C.C. 1979. Miller's anatomy of the dog. W.B. Saunders, Philadelphia, p.568-578. 
IBAMA 2001. Mamíferos Aquáticos do Brasil: Plano de Ação - Versão II. Instituto Brasileiro do Meio Ambiente e Recursos Naturais Renováveis, Ministério do Meio Ambiente, Brazil.

IUCN 2010. Red list of Threatened Species. Version 2010.1. International Union for the Conservation of Nature and Nature Resources. Available from <www.iucnredlist.org> Accessed April 22, 2010.

Jablonski N.G. \& Chaplin G. 2000. The evolution of human skin coloration. J. Hum. Evol. 39:57-106. doi:10.1006/jhev.2000.0403

King J.E. 1983. Seals of the world. British Museum (Natural History). Oxford University Press, London. 240p.

Kiviranta I., Tammi M., Lappalainen R., Kuusela T. \& Helminen H.J. 1980. The rate of calcium extraction during EDTA decalcification from thin bone slices as assessed with atomic absorption spectrophotometry. Histochemistry.68:119-127. doi: 10.1007/BF00489507

Knobil E., Neill J.D., Plant T.M., Knobil E.D. \& Neill D.E. 2006. Physiology of Reproduction. $3^{\text {rd }}$ ed. Elsevier, Amsterdam, p.771-826.

Laws R.M. 1956. Growth and sexual maturity in aquatic animals. Nature 4526:193-194.

Longui C.A. 2005. Cryptorchidism: Diagnosis and treatment. Arq. Bras. Endocrinol. Metabol. 49:165-171. doi: 10.1590/S0004-27302005000 100021

Machado A.S.D. \& Papa P.C. 2008. Anatomical features of the reproductive phenotype in female South-American fur-seals (Arctocephalus australis). Annals XXVII Congress of the European Association of Veterinary Anatomists, Budapest, Hungary, p.100-101. (Resumo)

Machado A.S.D. 2006. Estudo do sistema reprodutor masculino do Lobo-marinho-do-sul (Arctocephalus australis). Dissertação de Mestrado em Ciências, Faculdade de Medicina Veterinária e Zootecnia, Universidade de São Paulo, SP. 136p.

Matousek J. \& Klaudy J. 1998. Qualitative and quantitative analyses of seminal ribonuclease in reproductive tract fluids of bulls. Anim. Reprod. Sci. 51:111-118.

McKenna M.C. \& Bell S.K. 1998. Classification of mammals: Above the species level. Columbia University Press, New York. 631p.

McNeal J.E. 1981. The zonal anatomy of the prostate. Prostate 2:35-49. doi: 10.1002/pros.2990020105

Mendis-Handagama S.M. \& Siril Ariyaratne H.B. 2005. Leydig cells, thyroid hormones and steroidogenesis. Indian J. Exp. Biol. 43:939-962.

Merrick G.S., Butle W.M., Wallner K.E., Lief J.H., Anderson R.L., Smeiles B.J., Galbreath R.W. \& Benson M.L. 2002. The importance of radiation doses to the penile bulb vs. crura in the development of postbrachytherapy erectile dysfunction. Int. J. Radiat. Oncol. Biol. Phys. 54:1055-1062.

Mihalache G., Indrei A. \& Mihalache G.D. 1996. The vasa vasorum in the veins of the spermatic cord. Rev. Med. Chir. Soc. Med. Nat. Iasi. 100:180-182.

Moller A.P. 1989. Ejaculate quality, testes size and sperm production in mammals. Functional Ecology 3(1):91-96.

Nickel R., Schummer A., Seiferle E. \& Sack W. 1979. The Viscera of Domestic Animals. Springer-Verlag, New York. 401p.

Nogueira J.C., Godinho H.P. \& Cardoso F.M. 1977. Microscopic anatomy of the scrotum, testis with its excurrent duct system and spermatic cord of Didelphis azarae. Acta Anat. 99:209-219. doi: 10.1159/000144853

Patel G.K., Wilson C.H., Harding K.G., Finlay A.Y. \& Bowden P.E. 2006. Numerous keratinocyte subtypes involved in wound re-epithelialization. J. Invest. Dermatol. 126:497-502. doi: 10.1038/sj.jid.5700101

Pereira A. 2005. Sobreviventes do El Niño. Pesquisa FAPESP 112:48-51.

Qin D.N. \& Lung M.A. 2000. Studies on relationship between testicular capsule and sperm transport in rat testis. Asian J. Androl. 2:191-198.

Ramm S.A. 2007. Sexual selection and genital evolution in mammals: A phylogenetic analysis of baculum length. The American Naturalist 169(3):360-369.

Reidenberg J.S. 2007. Anatomical adaptations of aquatic mammals. Anat. Rec. 290:507-513. doi: 10.1002/ar.20541
Ridgway S.H. \& Harrison R.J.F.R.S. 1993. Handbook of Marine Mammals. Academic Press, San Francisco, p.161-208.

Rommel S.A., Pabst D.A. \& McLellan W.A. 2001. Functional morphology of venous structures associated with the male and female reproductive systems in Florida manatees (Trichechus manatus latirostris). Anat. Rec. 264:339-347. doi: 10.1002/ar.10022

Rybczynski N., Dawson M.R. \& Tedford R.H. 2009. A semi-aquatic Arctic mammalian carnivore from the Miocene epoch and origin of Pinnipedia. Nature 458:1021-1024. doi:10.1038/nature07985

Schaller C.G.M. \& Constantinescu G.M. 1999. Nomenclatura anatômica ilustrada. Manole, São Paulo. 614p.

Schambony A., Gentzel M., Wolfes H., Raida M., Neumann U. \& Töpfer-Petersen E. 1998. Equine CRISP-3: Primary structure and expression in the male genital tract. Biochim. Biophys. Acta 1387:206-216. doi:10.1016/ S0167-4838(98)00122-8

Scheffer V.B. 1967. Standard measurements of seals. J. Mammal. 48:459462.

Schiller D.M.M.M. 2000. Idade e desenvolvimento craniano do lobo-marinho-do-sul (Arctocephalus australis Zimmermann, 1783) (Carnivora: Otariidae), no litoral do Rio Grande do Sul, Brasil. Dissertação de Mestrado, Fundação Universidade do Rio Grande, RS. 117p.

Setchell B.P. 1998. The Parkes Lecture: Heat and the testis. J. Reprod. Fertil. 114(2):179-194.

Shafik A. 1995. Response of the urethral and intracorporeal pressures to cavernosus muscle stimulation: Role of the muscles in erection and ejaculation. J. Urol. 46:85-88.

Singh U.B. \& Bharadwaj M.B. 1978. Histological and histochemical studies on the testis of camel (Camelus dromedarius) during the various seasons and ages. Part II. Acta Anat. 101:280-288. doi: 10.1159/000144978

Sinha A.A., Erickson A.W. \& Seal U.S. 1977. Fine structure of seminiferous tubules in antarctic seals. Cell Tissue Res. 178(2):183-188.

Smiley A.K., Klingenberg J.M., Boyce S.T. \& Supp D.M. 2006. Keratin expression in cultured skin substitutes suggests that the hyperproliferative phenotype observed in vitro is normalized after grafting. Burns. 32:135-138.

Song G.S. \& Seo J.T. 2009. Relationship between ambient temperature and heat flux in the scrotal skin. Int. J. Androl. 32(4):288-294.

Stone B.A. 1981. Thermal characteristics of the testis and epididymis of the boar. J. Reprod. Fertil. 63:551-557. doi: 10.1530/jrf.0.0630551

Temte J.L. 1985. Photoperiod and delayed implantation in the northern fur seal (Callorhinus ursinus). J. Reprod. Fert. 73:127-131.

Trillmich F. \& Majluf P. 1981. First observations on colony structure, behavior and vocal repertoire of the South American Fur Seal (Arctocephalus australis Zimmerman, 1783) in Peru. Zeitschrift für Säugetierkunde 46(5):310-322.

Uhen M.D. 2007. Evolution of marine mammals: Back to the sea after 300 million years. Anat. Rec. 290(6):514-22.

Vaz-Ferreira R. \& Ponce de Leon A., 1984. Survey on Arctocephalus australis (Zimmermann, 1783) in Uruguay. Contribuciones del Departamento de Oceanografía, Universidad de la República, Montevideo, 1:18.

Vaz-Ferreira R. 1976. Arctocephalus australis (Zimmermann) South-American Fur-Seal. FAO - Scientific Consultation on Marine Mammals 49:13.

Wensing C.J. \& Colenbrander B. 1986. Normal and abnormal testicular descent. Oxf. Rev. Reprod. Biol. 8:130-164.

Werdelin L. \& Nilsonne A. 1999. The evolution of the scrotum and testicular descent in mammals: A phylogenetic view. J. Theor. Biol. 196:61-72. doi: $10.1006 /$ jtbi.1998.0821

Wilson M.J. \& Spaziani E. 1976. The melanogenic response to testosterone in scrotal epidermis: Effects on tyrosinase activity and protein synthesis. Acta Endocrinol. 81:435-448.

Yilmaz U., Yang C.C. \& Berger R.E. 2006. Dartos reflex: A sympathetically mediated scrotal reflex. Muscle Nerve 33:363-368. 